\title{
Seasonal histopathological alterations caused by Bothriocephalus acheilognathi in Schizothorax niger of Kashmir valley
}

\author{
Asifa Wali*, Masood-ul Hassan Balkhi ${ }^{1}$, Feroz A. Shah, Farooz Ahmad Bhat ${ }^{2}$, Bilal Ahmad Bhat ${ }^{3}$, Shabir Ahmad \\ Dar and Syed Shariq Nazir Qadiri \\ ${ }^{1}$ Division of Aquatic Animal Health Management, Faculty of Fisheries, Sher-e-Kashmir University of Agricultural \\ Sciences and Technology, Kashmir, Rangil Ganderbal (J\&K) India
}

\begin{abstract}
Liver and intestines affected by an cestode parasite viz., Bothriocephalus acheilognathi along with their host (Schizothorax niger) were collected randomly. Bothriocephalus acheilognathi causes damage to the intestinal tissues and induce complex host response; the affected fish were anemic and emaciated. The viscera were dark red on opening the abdomen. The intestinal contents showed lot of mucous and contained dark contents. The mucosal wall was red in colour and revealed necrotic surface. The histopathological changes were varied in severity with the season and parasitic burden. Intestinal infection of Bothriocephalus with Adenoscolex was usually seen together. Severe enteritis with heavy infilitration of inflammmtory cells and fibroblasts seen in lamina propia. Liver cells showed severe degenerative changes.
\end{abstract}

Key Words : Bothriocephalus acheilognathi, Schizothorax niger hyperplastic, Enteritis, Fibroblasts

View Point Article : Wali, Asifa, Balkhi, Masood-ul Hassan, Shah, Feroz A., Bhat, Farooz Ahmad, Bhat, Bilal Ahmad, Dar, Shabir Ahmad and Qadiri, Syed Shariq Nazir (2021). Seasonal histopathological alterations caused by Bothriocephalus acheilognathi in Schizothorax niger of Kashmir valley. Internat. J. agric. Sci., 17 (2) : 436-441, DOI:10.15740/HAS/IJAS/17.2/436-441. Copyright@2021: Hind Agri-Horticultural Society.

Article History : Received : 01.03.2021; Revised : 04.03.2021; Accepted : 17.03.2021

\footnotetext{
* Author for correspondence :

${ }^{1}$ Faculty of Fisheries, Sher-e-Kashmir University of Agricultural Sciences and Technology, Kashmir, Rangil Ganderbal (J\&K) India

${ }^{2}$ Division of Fisheries Resource Management, Faculty of Fisheries, Sher-e-Kashmir University of Agricultural Sciences and Technology, Kashmir, Rangil Ganderbal (J\&K) India

${ }^{3}$ Division of Social Sciences, Faculty of Fisheries, Sher-e-Kashmir University of Agricultural Sciences and Technology, Kashmir, Rangil Ganderbal $(\mathrm{J} \& \mathrm{~K})$ India
} 